\title{
Hydrolytic effects of acid and enzymatic pre-treatment on the anaerobic biodegradability of Ascophyllum nodosum and Laminaria digitata species of brown seaweed
}

Oluwatosin Obata, Joseph C. Akunna, Graeme Walker

This is the accepted manuscript (C) 2015, Elsevier. Licensed under the Creative Commons Attribution-NonCommercial-NoDerivatives 4.0 International (CC BY-NC-ND 4.0) http://creativecommons.org/licenses/by-nc-nd/4.0/

The published article is available from doi:

http://dx.doi.org/10.1016/j.biombioe.2015.05.001 
1 Hydrolytic effects of acid and enzymatic pre-treatment on the anaerobic

2 biodegradability of Ascophyllum nodosum and Laminaria digitata species of

3 brown seaweed.

4

5

6

7

\section{Oluwatosin Obata*, Joseph C. Akunna** and Graeme Walker*}

* School of Science, Engineering and Technology, Abertay University, Bell Street, Dundee DD1 1HG, Scotland, UK

** Urban Water Technology Centre, School of Science, Engineering and Technology, Abertay University, Bell Street, Dundee DD1 1HG, Scotland, UK. Tel: +44(0)1382 308141. E-mail: j.akunna@abertay.ac.uk (Corresponding author)

\section{ABSTRACT}

Abundant marine biomass in coastal regions has continued to attract increasing attention in recent times as a possible source of renewable energy. This study aimed to evaluate the effects of hydrolytic pre-treatment for the purpose of enhancing biogas yield of Laminaria digitata and Ascophyllum nodosum species found on the west coast of Scotland. Results show that L. digitata, in its natural and untreated form, appears to be more readily hydrolysable than $A$. nodosum. Two treatments were assessed: acid only and acid followed by enzyme. Both treatments enhanced the hydrolysis of both seaweed species, with acidenzyme treatment providing a better performance.

Keywords: Acid hydrolysis; acidogenesis; Ascophyllum nodosum; enzymatic hydrolysis; Laminaria digitata; volatile fatty acids production.

\section{INTRODUCTION}


The need for sustained energy security has led to the realization of the need for alternatives to fossil fuels $[1,2]$. This coupled with the need to mitigate greenhouse gas emissions, which is believed to be the major cause of climate change has simulated increased research into alternative energy sources [1,3-6]. In order to achieve global reduction in greenhouse gas emissions, countries across the world have set targets on the amount of energy to be generated from renewable sources. For instance, the European Union has set a binding target of $20 \%$ of energy use by member states to be generated from renewable sources by 2020 [1], while the USA plans to replace 75\% of its imported oil by renewable energy by 2025 [7]. Scotland aims to generate $100 \%$ of its electricity needs from renewable sources by $2020[8]$.

Various means of generating renewable energy including solar, wind, hydro, tidal and biomass energy have been reported in literature $[1,9,10]$. Biomass energy has received significant attention due to its availability, ease of utilisation and the relative maturity of the technology involved [1,10-12]. A huge amount of scientific publications on biomass energy $(56 \%)$ in relation to other sources of renewable energy has been published in the last 30 years [13]. Of particular interest is the use of marine biomass for renewable energy production $[12,14,15]$. Marine macroalgae have many advantages over terrestrial energy crops such as lack of competition with agricultural practices for land and high growth rates. It can also withstand different environmental and nutritional conditions and much is known about their cultivation processes. These factors make algae biomass a promising energy crop for increased energy security and greenhouse gas emission mitigation across the world and in the UK in particular $[1,15-17]$.

For efficient macroalgae conversion into energy, various components making up the biomass must be amenable to biodegradation. Alginate is the main structural compound and the 
most abundant polysaccharide in brown seaweed. While the intercellular matrix of the brown algae is dominated by alginate, the cell walls also contain cellulose, fucoidan and protein [18-20]. These polysaccharides are broken down during hydrolysis prior to biogas production. Another polysaccharide is laminarin, the main storage carbohydrate in Laminaria species. Fucoidan is another storage carbohydrate present in brown algae and made up of sulphated fucan. The absence of lignin and low cellulose content of algae makes it more suitable for microbiological conversion to energy fuels than terrestrial plants $[21,22]$. Since seaweeds have growth and primary production rates that exceed those of most terrestrial plants, the concerns over feed stock supply would be considerably reduced compared to terrestrial crop, when used for energy production $[16,23]$.

Seaweeds have been found to be suitable feedstocks for biogas production via anaerobic digestion processes $[19,21,24]$. This is due to the presence of readily hydrolysable sugars (e.g. alginate and laminaran) present in the seaweeds, with low amount of cellulose and zero lignin content [21]. However, hydrolysis remains the rate limiting step in the anaerobic digestion of biomass (including marine biomass) [11,14,25]. Different pre-treatment methods have been reported in literature to enhance hydrolysis of algal biomass including; mechanical chopping, grinding, ultrasonic treatment, ozone oxidation, thermal treatment, alkaline treatment and Fenton pre-treatment [14]. Others include heating and milling to reduce the particle size to $1-5 \mathrm{~mm}$. It has been reported that the process of releasing sugars from algal biomass can be enhanced by the combination of acid hydrolysis followed by treatment with a cocktail of different enzymes rather a single enzyme [26]. Enzymatic pretreatment employing multienzymatic preparations containing cellulase is reportedly effective in addressing the heterogeneous nature of the algal carbohydrates [27]. 
The aim of this study is therefore to determine the effects of acid and enzymatic pretreatment methods on two of the most common types of seaweeds, Laminaria digitata and Ascophyllum nodosum, using acid treatments and acid plus multienzymatic preparations.

\section{MATERIAL AND METHODS}

\subsection{Collection and preliminary treatment of seaweed samples}

The seaweed ( $A$. nodosum) was collected at Broughty Ferry beach, Dundee, UK while $L$. digitata was collected at Arbroath beach, UK in March, 2010. After collection, the seaweed was placed on foil covered trays and dried in a drying cabinet at $80^{\circ} \mathrm{C}$ for two days. The dried seaweeds were crushed and milled using a hammer mill (Retsch, fitted with a $1 \mathrm{~mm}$ screen) to create a powder that was used for the experiments. This was done to reduce the particle size to increase the surface area available for effective biodegradation [28]. The seaweed powder was stored in sealed containers at room temperature until used.

\subsection{Pre-treatment methods}

\subsubsection{Acid and heat pre-treatment}

Powdered seaweed (10 g) for Laminaria digitata and Ascophyllum nodosum, was weighed into $250 \mathrm{ml}$ Erlenmyer flasks in duplicate. $100 \mathrm{ml}$ of $0.2 \mathrm{M} \mathrm{H}_{2} \mathrm{SO}_{4}$ acid was added to each of the samples, then covered and autoclaved for 1 hour at $121^{\circ} \mathrm{C}$ and allowed to cool. After cooling, the $\mathrm{pH}$ was adjusted to $7.5 \pm 0.4$ using drops of $35 \% \mathrm{NH}_{4} \mathrm{OH}$ solution.

\subsubsection{Acid, heat and enzymatic hydrolysis}

An enzyme cocktail was added to the prepared samples from above (section 2.2.1). The commercial enzyme cocktail procured from Novozyme (Denmark) was used for the algal 
biomass hydrolysis in the following proportion: Cellulose $6 \% \mathrm{w} / \mathrm{w}, \beta$ - glucosidase $0.6 \% \mathrm{w} / \mathrm{w}$, Multi-complex $0.4 \% \mathrm{w} / \mathrm{w}$, Hemi-cellulase $2 \% \mathrm{w} / \mathrm{w}$ and Xylanase $0.25 \% \mathrm{w} / \mathrm{w}$, according to manufacturer instructions (Table 1). The enzymes were added to the mixture containing acid hydrolysed seaweeds after the $\mathrm{pH}$ has been adjusted to 5.5 (suitable for all enzymes) using drops of $35 \% \mathrm{NH}_{4} \mathrm{OH}$ solution. After the addition of the enzymes, the samples were incubated at $50^{\circ} \mathrm{C}$ and $100 \mathrm{rpm}$ for 18 hours. The $\mathrm{pH}$ dropped slightly after enzymatic hydrolysis to 4-5, but not below the required range for any of the enzymes (Table 1). After enzyme hydrolysis samples were cooled to room temperature and the $\mathrm{pH}$ corrected to $7.5 \pm 0.4$ using $35 \% \mathrm{NH}_{4} \mathrm{OH}$ solution.

Table 1. Enzyme parameters used in this study (information from Novozymes A/S)

\begin{tabular}{lllll}
\hline Enzyme & Activity & $\mathrm{pH}$ & $\begin{array}{l}\text { Temperature } \\
\left({ }^{\circ} \mathrm{C}\right)\end{array}$ & $\begin{array}{l}\text { Dose }(\% \mathrm{w} / \mathrm{w} \\
\text { seaweed })^{*}\end{array}$ \\
\hline $\begin{array}{l}\text { Cellulase } \\
\text { complex }\end{array}$ & 700EGU $\mathrm{g}^{-1}$ & $4.5-6.5$ & $45-60$ & 6.0 \\
B-Glucosidase & 250 & & \\
Multi-complex & $500 \mathrm{FXU}^{8} \mathrm{~g}^{-1}$ & $2.5-6.5$ & $45-70$ & 0.6 \\
Xynalase & 500FXU $\mathrm{g}^{-1}$ & $4.0-6.0$ & $40-65$ & 0.4 \\
Hemicellulose & 750FXU g-6.0 & $5.0-8.0$ & $35-55$ & 0.5 \\
\hline
\end{tabular}

*Dose values were calculated based on $10 \%$ seaweeds substrate.

${ }^{\varepsilon}$ Endoglucanase units ${ }^{\top} \beta$-Glucanase units ${ }^{\gamma}$ fungal xynalase units

\subsection{Anaerobic digestion}

\subsubsection{Culture media}

Non-growth synthetic medium was prepared for the anaerobic digestion process using the

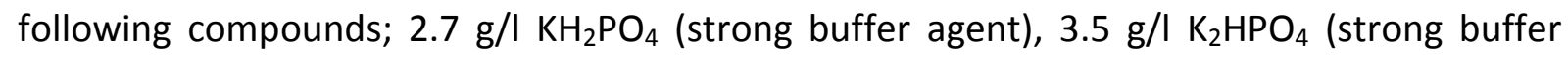
agent), $5 \mathrm{mg} / \mathrm{I} \mathrm{MgSO}_{4} .7 \mathrm{H}_{2} \mathrm{O}, 0.5 \mathrm{mg} / \mathrm{I} \mathrm{CaCl}_{2}, 0.5 \mathrm{mg} / \mathrm{l} \mathrm{FeCl}, 0.5 \mathrm{mg} / \mathrm{l} \mathrm{KCl}_{3}, 0.1 \mathrm{mg} / \mathrm{l} \mathrm{CoCl}_{2}$ and $0.1 \mathrm{mg} / \mathrm{I} \mathrm{NiCl}_{2}$. The medium provided the essential nutrients required by the microorganisms 
[29]. Anaerobically digested sludge was obtained from wastewater treatment plant in

Dundee (UK). The $\mathrm{pH}$ of the inoculum was 7.5 while the volatile solid content was $2.67 \mathrm{~g} / \mathrm{l}$.

\subsubsection{Experimental design}

Pre-treated feedstock $(110 \mathrm{ml})$ was diluted with $190 \mathrm{ml}$ of the non-growth medium and seeded with $100 \mathrm{ml}$ of anaerobically digested sludge to make up $400 \mathrm{ml}$ of culture volume in a $500 \mathrm{ml}$ capacity culture bottle for each of the experimental condition tested. The culture bottles were then purged with nitrogen gas and incubated at mesophilic temperature of $37^{\circ} \mathrm{C}$ for 25 days. Blank samples containing only the inoculum and medium were set up to discount anaerobic digestion activities due to residual substrates in the inoculum. The $\mathrm{pH}$ of the cultures was adjusted to 7.4 at the start of the experiment using drops of $35 \% \mathrm{NH}_{4} \mathrm{OH}$ solution. All experimental set-ups were prepared in duplicates. Samples of about $20 \mathrm{ml}$ were collected at regular intervals from each culture bottle and analysed for $\mathrm{pH}$, volatile fatty acids concentration, total and volatile solids.

\subsection{Analytical methods}

The protein content of the seaweed species was analysed employing the Coomassie (Bradford) protein assay. Proteins were extracted from seaweed powder using $2 \mathrm{M} \mathrm{NaOH}$ in a proportion of $10 \%$ seaweed powder and $90 \% \mathrm{NaOH}$, incubated at $65^{\circ} \mathrm{C}$ at $150 \mathrm{rpm}$ for 60 minutes. Samples were centrifuged and the supernatant used for the protein assay. Total carbohydrate content was determined by hydrolysis using the methods described in the NREL Chemical and Testing procedure (NREL 1996). The amount of reducing sugars and the specific sugars produced after acid and enzyme hydrolysis was determined using highperformance liquid chromatography (HPLC) analysis. $\mathrm{pH}$ was evaluated using $\mathrm{pH}$ meter 
Senslon $3(\mathrm{HACH})$. Gas produced in the batch reactors was measured with gas analyser GA

1432000 Geotechnical Instrument (England) after which the reactor bottles were sealed with

144 silicon to avoid gas leakages and maintain anaerobic conditions. Volatile fatty acids (VFAs)

145 concentrations of the anaerobic cultures were determined by esterification method [30].

146 Total and volatile solids content was determined according to standard methods [31].

\subsection{Statistical analysis}

Experimental error was determined for duplicate assays and expressed in standard

150 deviation. The significance of differences in reducing sugar yields and volatile acid formation were determined by one-way analysis of variance (ANOVA). Statistical significant 152 interactions were further analysed using post hoc test (Tukey) at 95\% confidence interval. Differences between species and across treatments were also determined. All statistical analyses were performed using Minitab Statistical Software version 17.0.

\section{RESULTS AND DISCUSSION}

\subsection{Algal composition}

Table 2 shows the composition of algae used in the study.

Table 2: Characterisation of experimental seaweeds prior to treatments and anaerobic digestion

\begin{tabular}{|c|c|c|}
\hline Component & A. nodosum & L. digitata \\
\hline Total Carbohydrate (\%) & 57.84 & 64.47 \\
\hline Protein (\%) & 2.12 & 2.64 \\
\hline Others $^{\mathrm{a}}(\%)$ & 20.52 & 13.12 \\
\hline Ash & 19.51 & 19.63 \\
\hline VS (\%) & 80.49 & 80.33 \\
\hline TS (\% wet solid) ${ }^{b}$ & 24.7 & 26.4 \\
\hline
\end{tabular}


163 Table 2 shows significant differences in the composition of both species of seaweed especially in both the protein $(P<0.032)$ and carbohydrate contents $(P<0.003)$, both of which are greater in L. digitata. These characteristics seem to suggest that the L. digitata is likely to be more readily biodegradable than $A$. nodosum. Algal biomass composition is known to vary depending on the time and season of harvest $[15,17,20]$. It has been reported that the amount of laminaran and mannitol present in L. digitata are lowest around March and reach a peak between June and July [15]. A similar trend has also been found for A. nodosum [19]. The seaweeds used for this study were harvested in March, suggesting that the total carbohydrate content shown in Table 2 may be considered as being lower than average value for the species.

\subsection{Effect of hydrolytic pre-treatment on the production of reducing sugar}

The effectiveness of the hydrolysis process in this study has been assessed by the determination of the amount and type of monomers produced. Figure 1 shows an increase in sugar production after enzymatic hydrolysis in both seaweed cultures.

During acid treatment, 11.8 and $10.11 \mathrm{~g} / \mathrm{l}$ of sugar were produced by $A$. nodosum and $L$. digitata respectively showing that sugars produced by $A$. nodosum was significantly higher than that of $L$. digitata $(P<0.015$. However, after further enzyme treatment there was significant increase $(P<0.0001)$ in reducing sugar production by L. digitata from 10.11 to 28.3 $\mathrm{g} / \mathrm{l}$. 


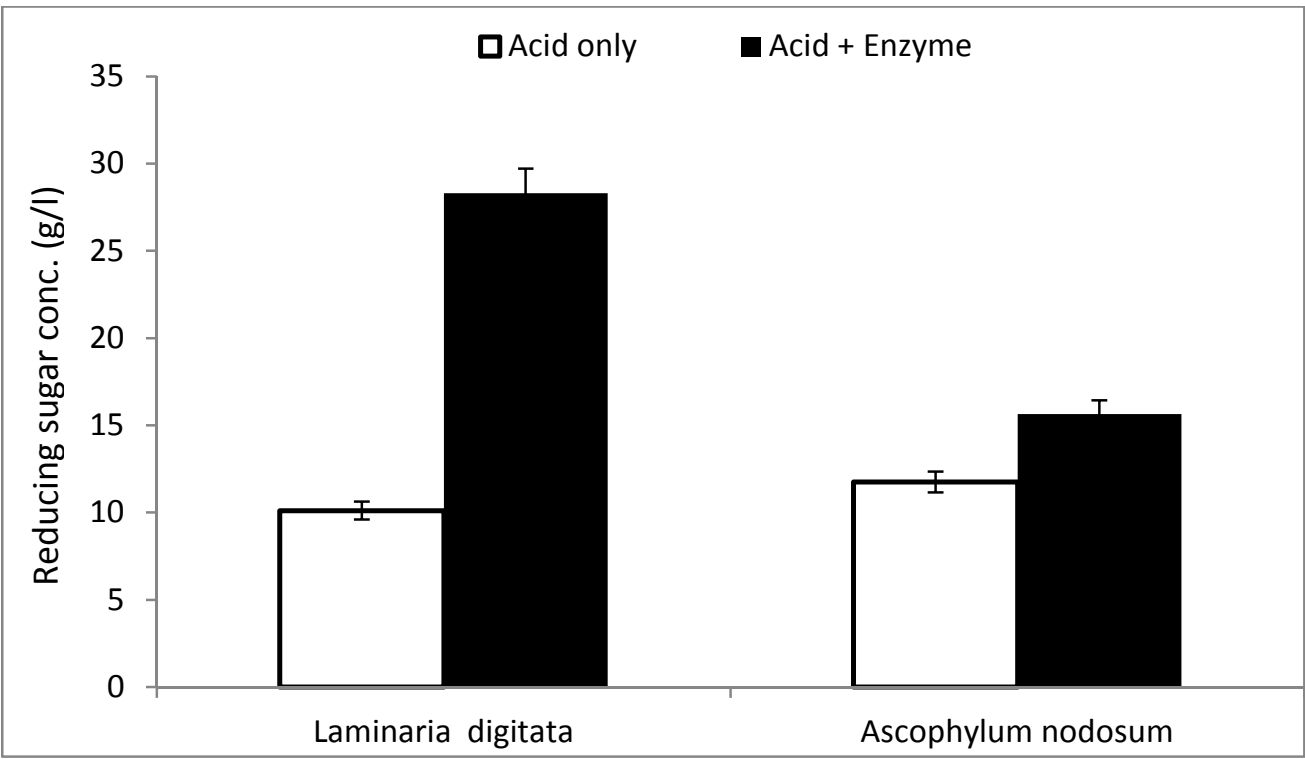

185

Figure 1. Reducing sugar concentration after acid and enzymatic hydrolysis of the two seaweeds.

Similarly, addition of hydrolytic enzymes to acid treated $A$. nodosum cultures resulted in significant increase in reducing sugars production $(P<0.002)$ from 11.8 to $15.64 \mathrm{~g} / \mathrm{l}$. Tukey's post hoc comparison of reducing sugar production between the two seaweeds cultures shows that significantly higher reducing sugars $(\mathrm{P}<0.0001)$ were produced by $L$. digitata than by $A$. nodosum after enzyme hydrolysis as $L$. digitata produced $81 \%$ more sugars.

Analysis of the specific monomers that make up the reducing sugars showed the presence of glucose, MGX, (mannose, galactose and xylose analysed together), rhamnose and fucose as shown in Figure 2.

For the L. digitata culture, glucose accounted for most (about 63\%) of the reducing sugar produced while rhamnose accounted for the highest amount $(55 \%)$ of the reducing sugar produced in the $A$. nodosum. This relative abundance of glucose in L. digitata compared to $A$. nodosum is likely to have significant impact on the relative rates of biodegradation of both seaweed species. The results of this study seem to support the literature reports that 
various bonds linking the polymers that make up algal biomass are broken during hydrolysis to produce monomers (sugars), which could readily be converted to bioenergy $[20,32]$.

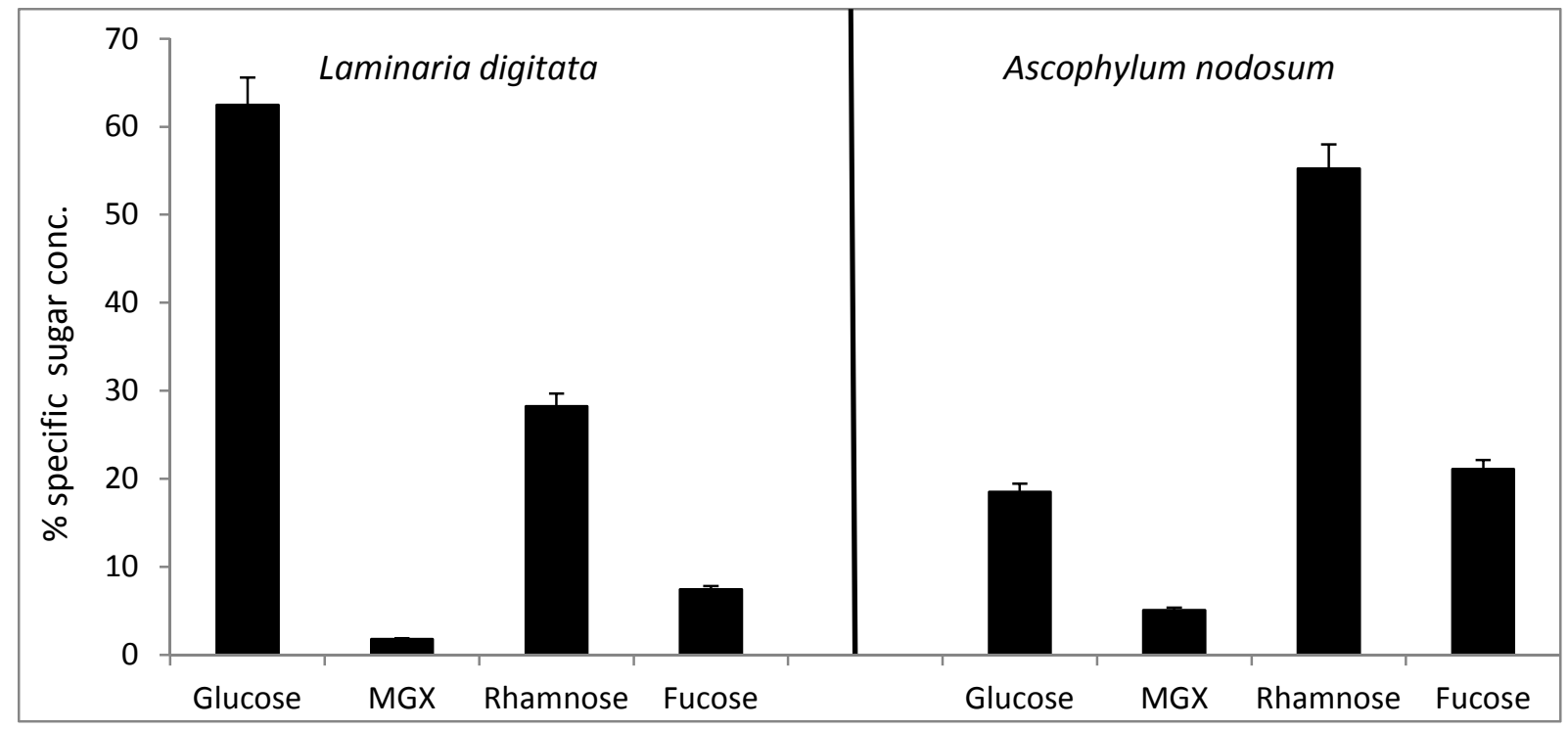

Figure 2. Percent specific sugar in L. digitata and A. nodosum after enzyme hydrolysis. (Note: MGX= Mannose + Galactose + Xylose $)$

\subsection{Effect of hydrolytic pre-treatment on anaerobic biodegradability of the seaweed} species

To evaluate the effect of the various pre-treatment methods used in the study on the anaerobic biodegradability of each of the seaweed species, anaerobic digestion of both treated and untreated seaweed samples was carried out over a period of 25 days. Gas was analysed (\%) and released during the digestion process (data not included). Negligible amounts of methane $(<1 \%)$ were recorded in all batches in the first 6 days of digestion. The acidogenic activity was used as a measure of the biodegradability potential of the various untreated and pre-treated seaweed species. Figures 3 and 4 show the volatile fatty acids (VFAs) production and accumulation obtained in each of the cultures during the 
6. Thereafter, a gradual decrease of the accumulated volatile fatty acids (VFAs)

220

221

222 concentration was observed, most likely due to their conversion to methane gas. The levels of VFAs production up to Day 6 were used to evaluate the immediate impact of the various pre-treatment methods used in this study on the substrates' level of biodegradability.

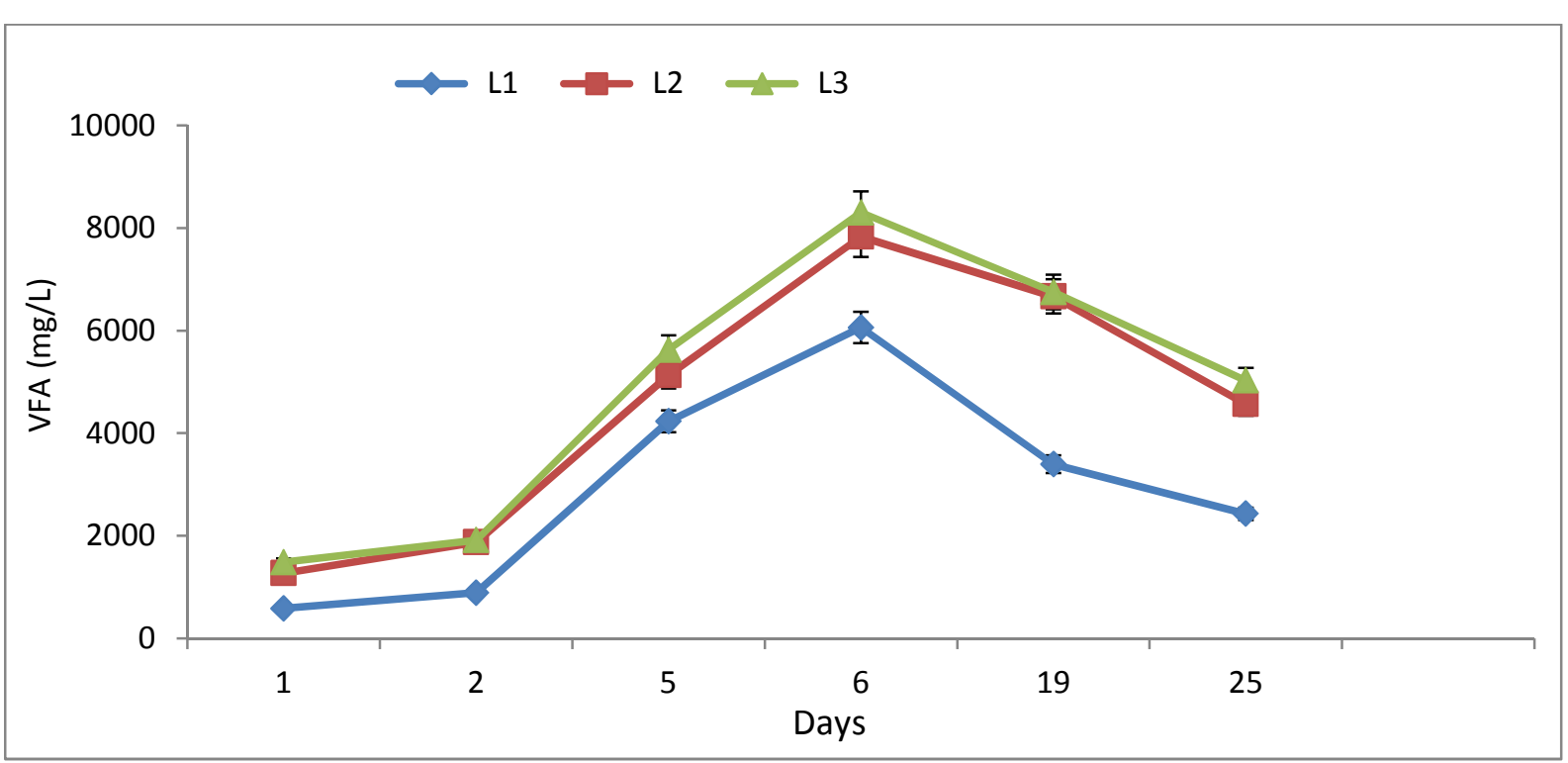

Figure 3. Volatile fatty acids accumulation in L. digitata cultures: L1: Untreated; L2: Acid treated; L3: Acid/enzyme treated

In general, VFAs production and accumulation were greater in cultures containing pretreated seaweeds. One-way analysis of variance of peak VFAs production by L. digitata on Day 6 shows that VFA production in acid treated $(L 2)$ was significantly higher $(P<0.001)$ than untreated (L1) cultures. This is an indication that hydrolysis was enhanced by the addition of acid. Further statistical analysis of results obtained from treated cultures highlighted a significantly higher VFAs production $(P<0.008)$ in enzyme treated $L$. digitata $(L 3)$ than acid only treated cultures (fig 3). This shows that the combination of acid and enzyme hydrolysis 

substrates.

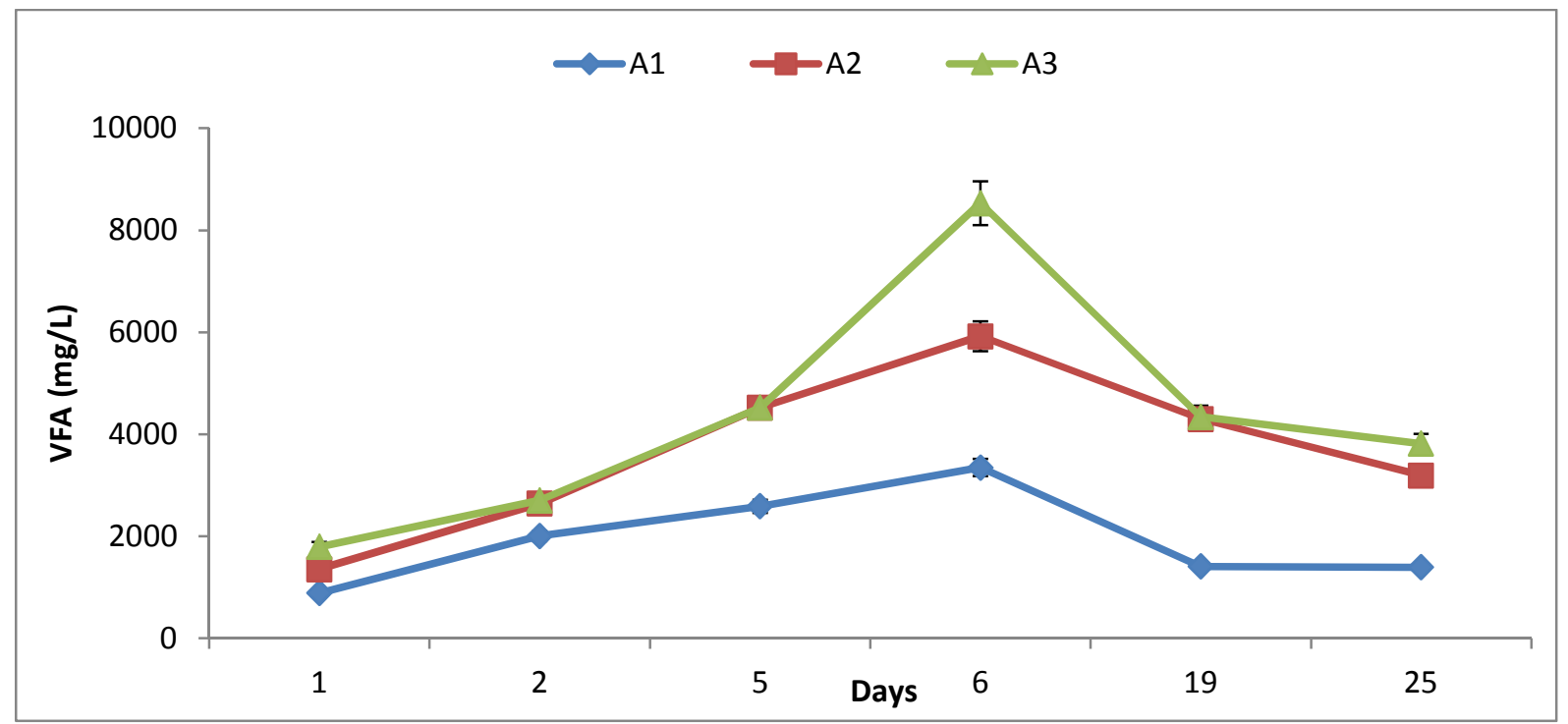

Figure 4. Volatile fatty acids production in A. nodosum cultures: A1: Untreated; A2: Acid treated; A3: Acid/enzyme treated

Analysis of VFAs production in A. nodosum cultures produced $3346 \mathrm{mg} / \mathrm{l}$ in untreated (A1) increase in fatty acids productions shows that it is statistically significant and suggests that addition of acids to A. nodosum biomass enhances its biodegradation. ANOVA and Tukey's

247 pairwise post hoc comparison between VFAs produced in the acid only and the enzyme treated $A$. nodosum cultures indicated that a significant increase occurred $(P<0.001)$ after 249 the addition of enzymes.

250 Comparison of VFAs production by untreated seaweeds (L1 and A1) on Day 6 shows that 251 VFAs produced by untreated L. digitata (L1) was $45 \%$ higher than VFAs obtained from 252 untreated $A$. nodosum (A1). Statistical analysis showed that this difference in VFA production 253 was significant $(P>0.001)$. This result indicates that untreated L. digitata is more readily 
biodegradable than $A$. nodosum. This result is consistent with the observations shown in Figures 1 and 2.

One-way ANOVA and post hoc analysis of VFAs production in acid treated cultures between the two seaweeds showed that significantly higher (24\%) levels of VFAs was recorded in acid treated L. digitata (L2) than in acid treated A. nodosum (A2) $(P>0.002)$. This suggests that acid pre-treatment of $A$. nodosum increases its biodegradability to a level comparable to that on untreated L. digitata (fig.3).

One-way ANOVA carried out on enzyme treated seaweeds ( $A 3$ and $L 3$ ) shows that there no significant difference in the amount of VFAs produced between L. digitata and A. nodosum ( $P>0.63)$. Tukey pairwise post hoc analysis at $95 \%$ confidence interval also confirmed that there's no significant difference between the means of VFAs produced by both seaweeds when treated with enzyme. Although significant differences were observed when both seaweeds were treated with acids, the differences observed diminished when the seaweeds were further subjected to enzymatic hydrolysis. This is despite the fact that L. digitata produced significantly higher concentration of reducing sugars. This might be due to the production of other fatty acids not detected by the esterification methods employed in their estimation.

In general, it can be seen that there is significant benefit in combining acid and enzyme pretreatment for both seaweed species.

\section{CONCLUSIONS}

This study has shown that acid and enzymatic pre-treatment of seaweed prior to anaerobic digestion can enhance their hydrolysis, with the level of impact dependent on the seaweed species. L. digitata, in its natural and untreated form, appears to be more readily 
hydrolysable than $A$. nodosum. The pre-treatments used in this study have been shown to

279 have a greater effcet on hydrolysis of $A$. nodosum than on L. digitata. Acid pre-treatment

280 alone can significantly enhance the hydrolysis of seaweed species. Enzymatic treatment

281 following acid-pre-treatment can further significantly improve on the hydrolysis of both 282 species of seaweed.

\section{ACKNOWLEDGEMENT}

285 This work was funded by the University of Abertay Dundee.

286

287

\section{REFERENCES}

288

[1] Costa JC, Gonçalves PR, Nobre A, Alves MM. Biomethanation potential of macroalgae 289 Ulva spp. and Gracilaria spp. and in co-digestion with waste activated sludge. 290 Bioresour.Technol. 2012 6;114:320-6.

291 [2] Demirbas A. Use of algae as biofuel sources. Energy Conversion and Management 2010 292 $12 ; 51(12): 2738-49$.

293 [3] Chynoweth DP, Owens JM, Legrand R. Renewable methane from anaerobic digestion of 294 biomass. Renewable Energy 2001;22(1-3):1-8.

295 [4] Agarwal AK. Biofuels (alcohols and biodiesel) applications as fuels for internal combustion 296 engines. Progress in Energy and Combustion Science 2007;33(3):233-71.

297 [5] Gnansounou E. Production and use of lignocellulosic bioethanol in Europe: Current 298 situation and perspectives. Bioresour.Technol. 2010 7;101(13):4842-50. 
299 [6] Talebnia F, Karakashev D, Angelidaki I. Production of bioethanol from wheat straw: An 300 overview on pretreatment, hydrolysis and fermentation. Bioresour.Technol. 2010 $301 \quad 7 ; 101(13): 4744-53$.

302

[7] Hahn-Hägerdal B, Galbe M, Gorwa-Grauslund MF, Lidén G, Zacchi G. Bio-ethanol - the fuel of tomorrow from the residues of today. Trends Biotechnol. 2006 12;24(12):549-56.

[8] Scottish Government. 2020 Routemap for Renewable Energy in Scotland. 2011; Available at: http://www.scotland.gov.uk/Publications/2011/08/04110353/3. Accessed 03, 2015.

[9] Demirbas MF, Balat M, Balat $H$. Potential contribution of biomass to the sustainable energy development. Energy Conversion and Management 2009 7;50(7):1746-60.

[10] Chang HN, Kim N, Kang J, Jeong CM. Biomass-derived Volatile Fatty Acid Platform for Fuels and Chemicals. Biotechnology and Bioprocess Engineering 2010;15(1):1-10.

[11] Raposo F, De la Rubia MA, Fernández-Cegrí V, Borja R. Anaerobic digestion of solid organic substrates in batch mode: An overview relating to methane yields and experimental procedures. Renewable and Sustainable Energy Reviews 2012 1;16(1):861-77.

[12] Matsui T, Koike Y. Methane fermentation of a mixture of seaweed and milk at a pilotscale plant. Journal of Bioscience and Bioengineering 2010 11;110(5):558-63.

[13] Manzano-Agugliaro F, Alcayde A, Montoya FG, Zapata-Sierra A, Gil C. Scientific production of renewable energies worldwide: An overview. Renewable and Sustainable Energy Reviews 2013 2;18:134-43. 
[14] Erden G, Filibeli A. Improving anaerobic biodegradability of biological sludges by Fenton

319 pre-treatment: Effects on single stage and two-stage anaerobic digestion. Desalination 2010 2;251(1-3):58-63.

[15] Adams JMM, Ross AB, Anastasakis K, Hodgson EM, Gallagher JA, Jones JM, et al.

322 Seasonal variation in the chemical composition of the bioenergy feedstock Laminaria 323 digitata for thermochemical conversion. Bioresour.Technol. 2011 1;102(1):226-34.

$324[16]$ Ross AB, Jones JM, Kubacki ML, Bridgeman T. Classification of macroalgae as fuel and its 325 thermochemical behaviour. Bioresour.Technol. 2008 9;99(14):6494-504.

326 [17] Adams JMM, Toop TA, Donnison IS, Gallagher JA. Seasonal variation in Laminaria 327 digitata and its impact on biochemical conversion routes to biofuels. Bioresour.Technol. $328 \quad 201111 ; 102(21): 9976-84$.

329 [18] Moen E, Horn S, Ostgaard K. Alginate degradation during anaerobic digestion of 330 Laminaria hyperborea stipes. J Appl Phycol 1997;9:157-66.

331 [19] Horn SJ. Bioenergy from brown seaweeds. : PhD Thesis, Department of Biotechnology, 332 Norwegian University of Science and Technology; 2000.

333 [20] Rioux L-, Turgeon SL, Beaulieu M. Characterization of polysaccharides extracted from 334 brown seaweeds. Carbohydr.Polym. 2007 6/25;69(3):530-7.

335 [21] Vergara-Fernándeza A, Vargasa G, Alarcónb N, Velascoc A. Evaluation of marine algae as 336 a source of biogas in a two-stage anaerobic reactor system. Biomass and Bioenergy 337 2008;32(4):338-44. 
338 [22] Sung-Soo J, Wakisaka M. I-lactic acid production from brown seaweed (Laminaria 339 japonica Areschoug) Extract. Journal of Bioscience and Bioengineering 2009 11;108, 340 Supplement 1:S133.

341 [23] Goh CS, Lee KT. A visionary and conceptual macroalgae-based third-generation 342 bioethanol (TGB) biorefinery in Sabah, Malaysia as an underlay for renewable and 343 sustainable development. Renewable and Sustainable Energy Reviews 2010 2;14(2):842-8.

344 [24] Kelly MS, Dworjanyn S. The potential of marine biomass for anaerobic biogas 345 production. Marine Estate Research Report. Scottish Association for Marine Science. 2008;.

346 [25] Migliore G, Alisi C, Sprocati AR, Massi E, Ciccoli R, Lenzi M, et al. Anaerobic digestion of 347 macroalgal biomass and sediments sourced from the Orbetello lagoon, Italy. Biomass 348 Bioenergy 2012 7;42:69-77.

349 [26] Daroch M, Geng S, Wang G. Recent advances in liquid biofuel production from algal 350 feedstocks. Appl.Energy 2013 2;102:1371-81.

351 [27] Yanagisawa M, Nakamura K, Ariga O, Nakasaki K. Production of high concentrations of 352 bioethanol from seaweeds that contain easily hydrolyzable polysaccharides. Process 353 Biochemistry 2011 11;46(11):2111-6.

354 [28] Yadvika, Santosh, Sreekrishnan TR, Kohli S, Rana V. Enhancement of biogas production 355 from solid substrates using different techniques-a review. Bioresour.Technol. 2004 356 10;95(1):1-10. 
357 [29] Akunna JC, Bizeau C, Moletta R. Nitrate and nitrite reductions with anaerobic sludge 358 using various carbon sources: glucose, glycerol, acetic acid, lactic acid and methanol. Water 359 Research 1993;27(8):1303-12.

360 [30] Montgomery HAC, Dymock JF, Thom NS. The rapid colorimetric determination of 361 organic acids and their salts in sewage-sludge liquor. Analyst 1962;87(1041):949-55.

362 [31] American Public Health Association, (APHA). Standard Methods for the Examination of 363 Water and Wastewater. In: Clesceri LS, Greenberg AE, Eaton AD, editors. . 20th ed. 364 Washington DC, USA: American Public Health Association, American Wastewater 365 Association, Water Environmental Federation; 1998.

366 [32] Gomez CG, Pérez Lambrecht MV, Lozano JE, Rinaudo M, Villar MA. Influence of the 367 extraction-purification conditions on final properties of alginates obtained from brown algae 368 (Macrocystis pyrifera). Int.J.Biol.Macromol. 2009 5/1;44(4):365-71. 